Hikmah: Journal of Islamic Studies, 17 (2), 2021, 118-134

http://journal.uinjkt.ac.id/index.php/HIKMAH

DOI: 10.47466/hikmah.v17i2.200. | P-ISSN. 2088-2629, E-ISSN. 2581-0146

\title{
KESEHATAN MENTAL PERSPEKTIF TAFSIR AL-MISBAH KARYA M. QURAISH SHIHAB
}

\author{
Hilmy Rabi'ah Nur*, Iffaty Zamimah \\ Institut Ilmu Al-Qur'an (IIQ) Jakarta, Indonesia \\ hilmy.ike@gmail.com
}

\begin{abstract}
This article discusses mental health in Muhammad Quraish Shihab's Tafsir Al-Misbah, which discusses verses related to mental health in the Qur'an. The conclusion of this article, first: mental health has a close relationship with faith and efforts to obtain and maintain mental health. With high faith accompanied by an attitude of patience, sincerity, gratitude, ridha, and piety and optimizing self-potential through remembrance and good deeds, mental health will be obtained which is marked by peace and tranquility and a happy life in the world and the hereafter, as well as the Qur'an. 'an is a psychotherapy for mental illness and psychosomatic illness. Second, M. Quraish Shihab's concept of mental health has relevance to modern mental health based on Abraham $H$. Maslow's hierarchy of needs theory. Faith and spirituality are at the level of the highest needs, namely self-actualization, and enjoyment of the world is at the level of the most basic needs, namely physiological needs. The concept of mental health from the perspective of M. Quraish Shihab's interpretation based on Maslow's hierarchy of needs can be described as follows: physiological needs, safety needs, social needs and self-actualization needs.
\end{abstract}

Keywords: peace; serenity; happiness, faith; mental health

\begin{abstract}
Abstrak
Artikel ini mengkaji ayat-ayat kesehatan mental dalam Al-Qur'an menurut perspektif Kitab Tafsir Al-Misbah karya Muhammad Quraish Shihab. Adapun hasil dari penelitian diantaranya adalah, pertama: kesehatan mental sangat berkaitan erat dengan keimanan dan upaya dalam memperoleh, menjaga kesehatan mental. Melalui Keimanan, kesabaran, ikhlas, syukur, ridha dan takwa kepada Allah yang disertai memaksimalkan potensi diri dengan zikir dan amal saleh, kesehatan mental akan hinggap pada kehidupan yang ditandai dengan munculnya ketentraman dan ketenangan hati serta kehidupan yang bahagia di dunia maupun nanti akhirat, serta Al-Qur'an merupakan psikoterapi bagi penyakit jiwa dan penyakit psikosomatik. Kedua, konsep kesehatan mental M. Quraish Shihab berkaitan dengan konsep kesehatan mental modern berdasarkan teori hierarki kebutuhan Abraham H. Maslow. Akidah dan spiritualitas berada pada tingkat kebutuhan tertinggi yaitu aktualisasi diri, dan kenikmatan dunia menempati tingkat kebutuhan paling dasar yaitu kebutuhan fisiologis. Konsep kesehatan mental perspektif penafsiran M. Quraish Shihab berdasarkan hierarki kebutuhan Maslow dapat diuraikan sebagai berikut: kebutuhan fisiologis, kebutuhan akan keamanan (safety needs), kebutuhan akan rasa memiliki dan kasih sayang (social needs), dan kebutuhan aktualisasi diri (self-actualization Needs).
\end{abstract}

Kata Kunci: ketentraman; ketenangan; kebahagiaan; keimanan; kesehatan mental 


\section{PENDAHULUAN}

Psikologis adalah salah satu faktor dalam menentukan sehat tidaknya seseorang. Mental adalah salah satu elemen pembentuk jiwa. kesehatan mental sangat penting untuk dijaga setiap saat, karena kuat secara fisik bukan berarti tidak memiliki jiwa yang sehat. Dapat dipastikan setiap orang menginginkan ketenangan hidup, sehingga mereka akan berupaya sekeras mungkin untuk mendapatkannya. akan tetapi, sayangnya tidak semua orang dapat mencapai apa yang diinginkannya. ${ }^{1}$ Kondisi hidup yang tak layak dapat menyebabkan konflik psikologis. Konflik psikologis jangka panjang berdampak pada perkembangan berbagai masalah kehidupan, termasuk kesepian, ketakutan, perilaku menyimpang, dan perkembangan gangguan psikosomatik. ${ }^{2}$ Indikasi penyakit ini adalah kelelahan, jantung berdebar-debar, lemas, dan sulit untuk berkonsentrasi. Selain itu, seperti sindrom, stres, trauma, ketergantungan obat penenang, atau perilaku menyimpang. Kedua, kondisi mental seseorang mempengaruhi kesehatan fisik atau fisiknya. ${ }^{3}$

Situs resmi Perhimpunan Dokter Jiwa (PDSKJI) memberikan data mengenaii kesehatan jiwa terkait pandemi COVID-19 yang cukup mencengangkan, sebanyak 64,3 dari 1.522 responden mengalami kecemasan atau depresi. Dari 1.522 responden, sebagian besar 76,1 adalah perempuan dengan usia minimal 14 tahun dan maksimal 71 tahun. Responden terbanyak berasal dari Jawa Barat 23,4\%, DKI Jakarta 16,9\%, Jawa Tengah 15,5\% dan Jawa Timur 12,8\%. Self-diagnosis kesehatan mental yang terkait dengan Covid-19 berfokus pada tiga masalah kesehatan mental: kecemasan, depresi, dan trauma. ${ }^{4}$

Berdasarkan data yang diperoleh di atas, hal itu menunjukkan bahwa penyakit mental tidak bisa dipandang sepele. Menurut perspektif kesehatan mental, Islam menilai hubungan kepada Allah sebagai sumber kebahagiaan, sehingga kebahagiaan dunia dan akhirat dunia adalah ukuran kebahagiaan sejati. Al-Qur'an memiliki ayat-ayat yang berkaitan dengan kesehatan mental dan menggunakan istilah yang berbeda sebagai hal yang ingin diraih manusia. Untuk memahaminya, diperlukan penafsiran oleh para ahli mufassir, salah satunya dari Kitab Tafsir Al-Misbah karya M. Quraish Shihab. Maka berangkat dari hal itu, penulis tertarik untuk melakukan penelitian mengenai kesehatan mental dalam AlQur'an perspektif Tafsir Al-Misbah.

\footnotetext{
${ }^{1}$ Ratnawati, "Metode Perawatan Kesehatan Mental dalam Islam", dalam Islamic Counseling: Jurnal Bimbingan dan Konseling Islam, Vol., No. 1, 2019, h. 71.

${ }^{2}$ Malikah, "Pendidikan Kesehatan Mental Melalui Bacaan Al-Qur'an (Studi Kasus di Pesantren Darullughah Wadda'wah Raci Bangil Pasuruan dan Pesantren Al-Amanah Bilingual Junwangi Krian Sidoarjo)”, Disertasi, (Surabaya: Pascasarjana UIN Sunan Ampel , 2018), h. 11.

${ }^{3}$ Alam Budi Kusuma, "Pendekatan Psychoterapy Al-Qur'an dalam Gangguan Kesehatan Mental (Suatu kajian Psikologi Agama)”, dalam Jurnal Komunikasi dan Pendidikan Islam, Vol. 5, No. 1, Juni 2016, h. 130.

4 Abdul Aziz, "Survei: 64,3\% dari 1.522 Orang Cemas dan Depresi Karena Covid-19", http://tirto.id/survei-643-dari-1522-orang-cemas-depresi-karena-covid-19-fgPG, pada 1 Mei 2021 diakses pada tanggal 09 April 2021.
} 


\section{METODE}

Jenis penelitian yang dilakukan adalan kepustakaan (library research), yaitu pengkajian pada literatur yang berkenaan dengan penulisan karya ini yaitu mengenai kesehatan mental prospek Tafsir Al-Misbah. Jenis penelitian pustaka ini adalah penelitian kualitatif. Adapun sumber primer yang digunakan adalah Al-Qur'an disertai dengan Terjemahannya dan kitab Tafsir Al-Misbah karya M. Quraish Shihab. sumber sekunder yang digunakan diperoleh dari berbagai data, buku-buku serta artikel yang bersinggungan dengan kesehatan mental. Metode penulisan yang digunakan bersifat deskriptif analitis, adapun teknik pengumpulan data menggunakan teknik dokumentasi yaitu pengumpulan data berupa ayat-ayat yang bersangkut paut dengan kesehatan mental yang terdapat dalam kitab Tafsir Al-Misbah karya M. Quraish Shihab, serta data-data lainnya.

\section{HASIL DAN PEMBAHASAN}

\section{Sekilas Tentang Tafsir Al-Misbah}

Pengertian Al-Misbah jika dilihat dari kacamata kebahasaan bermakna "lampu, pelita, atau lentera." Hal itu menunjukkan bahwa cahaya Al-Qur'an dapat memberi lentera pada makna kehidupan dan beraneka macam masalah hidup yang dijumpai manusia. Quraish Shihab berusaha untuk membuat Al-Qur'an lebih membumi dan membuat isinya dapat dipahami oleh pembaca. ${ }^{5}$ Tafsir ini mulai disusun oleh Muhammad Quraish Shihab pada hari Jum'at yang bertepatan pada tanggal 4 Rabi'ul Awal $1420 \mathrm{H}$ atau dalam kalender masehi tanggal 18 Juni 1999. Pada saat itu beliau tengah menjabat sebagai Duta Besar RI di Kairo, Mesir. Penulisan Tafsir Al-Misbah rampung di Jakarta 5 September 2003 hari Jumat. Tafsir Al-Misbah ditulis dalam rangkaian 15 jilid meliputi 30 Juz Al-Qur`an. Ada dua jenis model cetak, satu dicetak dalam tampilan normal dan tampilan lux dengan hardcover. ${ }^{6}$ Tafsir ini diterbitkan oleh Lentera Hati yang berbasis di Ciputat dan telah dicetak ulang sebanyak sembilan kali sejak edisi pertamanya dari tahun 2003 hingga 2008.

Dapat dikatakan Tafsir Al-Misbah adalah karangan kedua tafsir yang ditulis oleh M. Quraish Shihab karena karya tafsir Beliau yang pertama adalah Tafsir Al-Qur'an Al-Karim, namun tafsir ini kurang menarik untuk disajikan secara umum, bahkan ada yang mengkritik penyajiannya terlalu panjang. Hal ini membuat M Quraish Shihab tidak puas dengan karyanya tersebut, kemudian ia membuat sebuah tafsir yang mengutarakan pengkajian pada setiap surat dengan terlebih dahulu menjelaskan pokok bahasan surat

\footnotetext{
${ }^{5}$ Lufaefi,"'Tafsir Al-Misbah: Tekstualitas, Rasionalitas, dan Lokalitas Tafsir Nusantara”, dalam Jurnal Substantia Vol. 21 No. 1 April 2019, h. 31.

${ }^{6}$ Metodologi Tafsir Al-Misbah Karya M. Quraish Shihab, http://digilib.iunsgd.ac.id, diakses pada 18 Juli 2021, h. 118.

${ }^{7}$ Zaenal Arifin, “Karakteristik Tafsir Al-Misbah”, dalam Jurnal Al-Ifkar Vol. 13 No. 01, Maret 2020, h. 5.
} 
tersebut. Dengan adanya keterangan mengenai tema dan tujuan surat, M. Quraish Shihab mencoba membuka isi Al-Qur'an dengan "Pesan, Kesan, Keserasian" dengan cara yang dapat dipahami pembaca. ${ }^{8}$

Adapun maksud dan tujuan M. Quraish Shihab menulis kitab Tafsir Al-Misbah adalah $^{9}:$ 1) Sebagai upaya memberi kontribusi langkah-langkah sederhana bagi Umat Islam untuk mengetahui esensi yang dikandung dalam Al-Qur'an dengan cara mengelaborasi informasi-informasi Al-Qur'an dan menjelaskan topik yang bersinggungan dengan pertumbuhan garis suratan tangan kehidupan manusia secara rinci; 2) Adanya kekeliruan di kalangan Umat Islam dalam menafsirkan fungsi Al-Qur'an. Seperti contoh, tradisi membaca Q.S Yasin secara berkala, tetapi mereka tidak memahami kandungan dari apa yang mereka baca itu; 3) kesalahan tersebut tidak hanya menyebar ke tingkat masyarakat awam tentang ilmu agama, tetapi juga ke komunitas berpendidikan yang bergerak di dunia penelitian Al Qur'an. Bahkan banyak dari mereka yang tidak mengenal bahwa sistematika penulisan Al-Qur'an memuat dimensi pendidikan yang luar biasa menyentuh jika dibandingkan dengan karya ilmiah; 4) Desakan dari Umat Islam Indonesia yang menggugah hati dan membangungkan tekad M. Quraish Shihab untuk menyusun sebuah kitab tafsir.

\section{Sumber, Metode, Corak, dan Sistematik Tafsir Al-Misbah}

Sumber penafsiran Al-Misbah didasarkan pada dua hal, pertama: berpangkal dari ijtihad penulis, kedua: memakai sumber literatur yang berasal dari pendapat dan fatwa para ulama terdahulu maupun ulama yang masih hidup saat ini. Diantara pendapat ulama yang menjadi sumber penafsiran yaitu Ibrahim Ibn Umar al-Biqa’i (w. 885 H/1480 M), Sayyid Muhammad Thantawi (w. 2010 M), Syeikh Mutawalli Sya'rawi (w. 1998 M), Sayyid Quthub (w. 1966 M), M. Thahir Ibn Asyur (w. 1392 H/1973 M), Sayyid Muhammad Husein Thaba'taba'i (w. $1981 \mathrm{M}$ ) dan lainnya. ${ }^{10}$

M. Quraish Shihab mengaplikasikan metode tahlili untuk Tafsir Al-Misbah, adapun pengertian dari metode tahlili sendiri adalah suatu kaidah dalam menafsirkan Al-Qur'an dengan menganalisis ayat-ayat Al-Qur'an berdasarkan ayat demi ayat, surat demi surat, sesuai dengan urutan Mushaf Utsmani. ${ }^{11}$ Penafsirannya dimulai dengan menafsirkan Surah Al-Fatihah sampai Surat An-Nas. Serta Beliau juga menjabarkan semua kosa kata atau pengucapan dari segi gramatikal dan makna. penguraian gramatikal mencakup keindahan

\footnotetext{
${ }^{8}$ Muhammad Alwi HS, dkk, “Gerakan Membumikan Tafsir Al-Qur'an di Indonesia: Studi M. Quraish Shihab atas Tafsir Al-Misbah”, dalam Jurnal Al-Tibyan: Jurnal Ilmu Al-Qur’an dan Tafsir Vol. 5 No. 1, Juni 2020, h. 96.

9 Atik Wartini, "Corak Penafsiran M. Quraish Shihab dalam Tafsir Al-Misbah", dalam Jurnal Hunafa: Jurnal Studia Islamika, Vol. 11 No. 1, Juni 2014, h. 112-113.

${ }^{10}$ Iffaty Zamimah, Al-Wasathiyyah dalam Al-Qur'an (Studdi Tafsir Maraghi, Al-Munir, dan Al-Misbah), (Tangerang: IIQ Jakarta Press, 2019), h. 95.

${ }^{11}$ Lufaefi,'”Tafsir Al-Misbah: Tekstualitas, Rasionalitas, dan Lokalitas Tafsir Nusantara”, h. 32.
} 
pola kalimat, ijaz, badi', ma'ani, bayan, haqiqat, majaz, kinayah, isti'arah, dan sebagainya. Dari segi makna meliputi maksud dari ayat, hukum, akidah, moral, perintah , larangan, relevansi ayat sebelum dan sesudahnya, hikmah dan sebagainya. ${ }^{12}$

Tafsir Al-Misbah lebih condong pada gaya penafsiran sastra budaya dan kemasyarakatan (adabi al-ijtima'i) yaitu corak tafsir yang berusaha memahami ayat-ayat AlQur'an dengan cara memaparkan pesan-pesan Al-Qur'an secara akurat, kemudian dilanjutkan dengan mengemukakan makna-makna yang terkandung di dalamnya dengan bahasa yang elok dan menarik, dan mufassir berupaya untuk mengintegrasikan teks-teks Al-Qur'an yang dikaji dengan realita sosial dan sistem budaya yang ada. Gaya penafsiran ini ditekankan tidak hanya pada tafsir lughawi, fiqh, ilmi dan isyari tetapi penafsirannya ditekankan pada kebutuhan masyarakat dan sosial masyarakat yang kemudian disebut corak tafsir Adabi al-Ijtima'i. ${ }^{13}$ Di sisi lain, Atik Wartini dalam bukunya "Corak Penafsiran M. Quraish Shihab dalam Tafsir Al-Misbah”, menyimpulkan bahwasanya, M. Quraish Shihab dalam menafsirkan turut menggunakan corak objektifis modernis, yaitu interpretasi yang membahas kosa kata, munasabah ayat, dan asbab an-nuzul ayat, serta memakai pendekatan sains dalam sebagian penafsirannya. walaupun dalam penafsirannya, M. Quraish Shihab acapkali memakai riwayat kemudian ra'yu. ${ }^{14}$

Bila dilihat dari struktur penulisan, Tafsir Al-Misbah menggunakan jenis tafsir tartib mushafi, yaitu sebuah gaya atau jenis penafsiran yang memakai urutan ayat atau suratnya sesuai dengan urutan ayat atau surat Al-Qur'an. Ayat atau surat yang pertama ditafsirkan adalah surat Al-Fatihah dilanjutkan Al-Baqrah dan seterusnya hingga terakhir surat AnNas. ${ }^{15}$ Mula-mula Quraish Shihab menjelaskan maksud dan tujuan firman Allah, juga mencantumkan gagaasan orientalis yang memberi suara miring dengan tajam tatanan sistematis ayat dan surat-surat Al-Qur'an disertai dengan mempersalahkan para penulis wahyu. Lebih dari itu, Tafsir Al-Misbah memberikan banyak pemaparan kepada sejumlah mufassir terkenal, menjadikannya referensi yang layak, informatif dan kontroversial. ${ }^{16}$

M. Quraish Shihab dalam Tafsir Al-Misbah menggunakan model yang dibuat para ulama terdahulu dalam menafsirkan, mencantumkan argumen-argumennya diantara terjemahan ayat yang sedang beliau tafsirkan. Beliau juga menggunakan tulisan cetak miring (italic) dalam kalimat terjemahan untuk membedakan antara terjemahan ayat dan komentarnya. Disela komentarnya tersebut, ia melakukan elaborasi terhadap pemikiran

\footnotetext{
${ }^{12}$ Rian Adriansyah, ”Konsep Akal Dalam Tafsir Al-Misbah", h. 48.

${ }^{13}$ Ali Geno Brutu, "Tafsir Al-Misbah: Muhammad Quraish Shihab", dalam Jurnal Online Preprints, Vol. 14, 2017, h. 6.

${ }^{14}$ Muhammad Alwi HS, dkk, “Gerakan Membumikan Tafsir Al-Qur'an di Indonesia: Studi M. Quraish Shihab atas Tafsir Al-Misbah”, h. 98.

${ }^{15}$ Zaenal Arifin, "Karakteristik Tafsir Al-Misbah", h. 14.

${ }^{16}$ Rian Adriansyah, ”Konsep Akal Dalam Tafsir Al-Misbah”, h. 41-43.
} 
para ulama, di samping pemikiran dan hasil ijtihadnya sendiri. ${ }^{17}$ Selain itu dalam menafsirkan beliau tidak menafsirkan ayat perayat dulu melainkan mengelompokkannya ke dalam beberapa ayat yang mempunyai hubungan satu sama lain, lalu beliau menjelaskan tafsirannya menjadi ayat perayat.

Berikut sistematika penulisan kitab Tafsir Al-Misbah yang dilakukan oleh M. Quraish Shihab: memaparkan pengertian dari nama surat, memberi penjelasan tentang isi kandungan ayat, menjelaskan ayat-ayat di awal mula penjelasan, memberi pengertian ayat secara garis besar, memberi paparan tentang kosa kata, menganggap satu surat adalah satu kesatuan ayat-ayat yang selaras..

\section{Tinjauan Umum Tentang Kesehatan Mental}

kesehatan mental didefinisikan oleh WHO adalah kondisi sejahtera (well-being) bagi mereka yang memahami kemampuan mereka, bergeming dari tekanan kehidupan normal, bekerja secara produktif, dan berkontribusi pada masyarakat. ${ }^{18}$ Pengertian lainnya mengenai Kesehatan jiwa diantaranya adalah luput dari gangguan dan penyakit jiwa, kemampuan beradaptasi, mengatasi masalah dan goncangan umum, harmonisasi fungsi jiwa (tidak ada konflik), berharga dan berguna serta bahagia dan dapat menggunakan potensi yang ada padanya seoptimal mungkin. ${ }^{19}$

Definis lain yang dipaparkan mengatakan, bahwa kesehatan mental adalah kesejahteraan psikologis, luput dari sakit mental, atau kondisi psikologis seseorang yang berperan aktif dalam meraih kebagahagiaan emosional dan penyesuaian tingkah laku. Dalam perspektif psikologi positif, kesehatan mental mencakup kapabilitas seorang individu untuk menyenangi kehidupan, melakukan beragam aktivitas secara proporsional, dan berjerih payah untuk mencapai resiliensi ${ }^{20}$ psikologis. $^{21}$

Secara keilmuan, kesehatan mental (mental health) adalah kajian ilmu yang merangkum sistem prinsip, aturan, dan metoder untuk menaikkan kesehatan jiwa. Kesehatan mental meliputi wawasan dan prinsip-prinsip dari bidang psikologi, kedokteran, psikiatri, biologi, sosiologi, dan agama. ${ }^{22}$

\footnotetext{
${ }^{17}$ Rian Adriansyah, h. 44.

${ }^{18}$ Widiya A Radiani, “Kesehatan Mental Masa Kini dan Penanganan Gangguannya Secara Islmai”, dalam Journal of Islamic and Law Studies, Vol. 3, No. 1, Juni 2019, h. 94.

${ }^{19}$ Zakiah Drajat, Islam dan Kesehatan Mental, (Jakarta: Gunung Agung, 1983), h. 9.

${ }^{20}$ Kemampuan umum yang melibatkan kemampuan penyesuaian diri yang tinggi dan luwes saat dihadapkan pada tekanan baik dari internal maupun eksternal.

${ }^{21}$ Syamsu Yusuf, Kesehatan Mental perspektif Psikologis dan Agama, (Bandung: PT Remaja Rosdakarya, 2018), h. 28.

${ }^{22}$ Samain, “Konsep Kesehatan Mental dalam Al-Qur'an dan Implikasinya Terhadap Adversity Quotient Perspektif Tafsir Al-Misbah”, Tesis, (Salatiga: IAIN Salatiga, 2020), h. 20.
} 
Berdasarkan definisi yang telah dikemukakan di atas mengenai kesehatan mental, dapat dirangkumkan bahwasanya, kesehatan mental selain dihitung sebagai sebuah keilmuan, kesehatan mental juga masuk sebagai suatu keadaan seseorang yang terbebas dari gangguan atau penyakit mental, mempunyai kemampuan untuk menuntaskan masalah dan rintangan kehidupan, berkapabilitas dalam menyesuaikan dengan diri sendiri dan lingkungannya, dan kuasa menggunakan potensi yang ada pada dirinya sendiri semaksimal mungkin.

\section{Prinsip Kesehatan Mental}

Prinsip mental hygiene merupakan aturan atau standar yang harus diterapkan dalam berusaha untuk meraih dan menjaga kesehatan mental dan penyesuaian yang baik dan untuk mencegah munculnya kesulitan-kesulitan psikologis (Alexander A. Schneiders, 1964). Untuk merumuskan asas-asas mental hygiena, perlu melihat kepada dasar dan kriteria kesehatan mental, keadaan-keadaan yang berdampak pada hubungan antara kesehatan mental atau kepribadian dan berbagai aspek-aspek lainnya. asas-asas ini berlandaskan pada beberapa kategori, yaitu takdir manusia sebagai makhluk hidup, ikatan jalinan antara manusia dengan lingkungan dan Tuhan. ${ }^{23}$

\section{Indikator dan Ciri-Ciri Kesehatan Mental}

Bersumber pada orientasi dan wawasan kesehatan mental, WHO menentukkan parameter kesehatan mental yang diantaranya adalah tidak terkungkung dengan kegelisahan dan kekhawatiran; menerima kegagalan sebagai pelajaran di hari yang akan datang; dapat melaraskan diri secara positif pada realitas walaupun pahit; dapat menjalin ikatan dengan orang lain serta saling tolong menolong; merasa lebih bahagia memberi daripada menerima; dapat merasa senang dari perjuangan dalam hidupnya; membelokkan rasa permusuhan pada pemecahan masalah yang kreatif serta konstruktif; mempunyai rasa kasih sayang serta memerlukan untuk disayangi; memiliki spiritual atau agama. ${ }^{24}$

Selain itu, Zakiah Darajat (1929) menentukkan parameter kesehatan mental dengan menyertakan komponen keimanan dan ketakwaan, sebagai berikut: 1) Terhindar dari gangguan dan penyakit jiwa; 2) Terwujudnya keselarasan antara elemen-elemen kejiwaan; 3) berkapabilitas untuk menyesuaikin diri secara luwes dan menciptakan jalinan hubungan yang berfaedah dan menentramkan antara individu; 4) berkapabilitas dalam memajukan potensi diri serta menggunakannya untuk diri sendiri dan orang lain; 5) Beriman dan bertakwa kepada Allah serta selalu berikhtiar untuk menunaikan tuntutan agama dalam

\footnotetext{
${ }^{23}$ Syamsu Yusuf, Kesehatan Mental perspektif Psikologis dan Agama, h. 16.

${ }^{24}$ Ramayulis, Psikologi Agama, (Jakarta: Kalam Mulia, 2013), h. 162.
} 
aktivitas sehari-hari sebagai akibatnya tercipta kehidupan yang bahagia di dunia dan akhirat. ${ }^{25}$

Berhubungan dengan karakteristik dan parameter kesehatan mental, Marie Jahoda (w. 2001) sebagaimana yang dikutip Jaelani pada buku "Penyucian Jiwa (Tazkiyat An-Nafs) dan Kesehatan Jiwa", memberi pengertian yang agak luas. Menurutnya, kesehatan mental tidak hanya berkaitan pada kemerdekaan seseorang dari gangguan kejiwaan dan penyakitnya. Walakin, orang yang sehat mentalnya memiliki karakter utama sebagai berikut: 1) Mampu memahami diri sendiri dengan baik; 2) Pertumbuhan, perkembangan, dan perwujudan diri yang baik; 3) Integrasi diri yang meliputi keseimbangan mental, kesatuan pandangan, dan tahan terhadap tekanan-tekanan yang terjadi; 4) kemandirian diri yang meliputi elemen-elemen pengendali kelakuan dari dalam atau kelakuan-kelakuan bebas; 5) Persepsi mengenai realitas, terhindar dari kesesatan kebutuhan, serta mempunyai empati dan sensitivitas sosial; 6) Berkapabilitas untuk mengendalikan lingkungan dan berintegrasi dengannya secara baik. ${ }^{26}$

\section{Gangguan Kesehatan Mental}

Gangguan mental atau istilah lain mental disorder adalah penyakit, gangguan, dan kekacauan fungsi mental atau kesehatan mental, lantaran tidakk berhasil untuk mereaksinya mekanisme adaptasi dari fungsi-fungsi kejiwaan terhadap stimuli ekstern ${ }^{27}$ dan ketegangan-ketegangan; sehingga lahir gangguan fungsional atau gangguan struktural dari satu bagian, satu orang, atau sistem kejiwaan/mental. ${ }^{28}$

Gangguan jiwa adalah suatu penyakit yang muncul karena adanya kekalutan pikiran, persepsi, dan tingkah laku, dimana individu tidak kuasa untuk mengikuti kondisi menyesuaikan diri sendiri, orang lain, masyarakat, dan lingkungan. Secara global gangguan jiwa muncul karena adanya tegangan psikologis dampak adanya tekanan dari luar juga pada individu tadi. Adapun yang disebut sebagai Gangguan jiwa diantaranya adalah berupa psikopat, kecemasan, fobia, antisosial, gangguan pencerahan, penyimpangan sosial. ${ }^{29}$

Gangguan mental dapat digambarkan sebagai perilaku abnormal yang menyimpang dari norma yang berlaku pada suatu komunitas, perilaku tersebut baik berbentuk pikiran,

\footnotetext{
${ }^{25}$ Ramayulis, Psikologi Agama, h.155.

${ }^{26}$ Ikhwan Fuad, "Menjaga Kesehatan Mental Perspektif Al-Qur'an dan Hadis”, dalam Jurnal An-Nafs: Kajian dan Penelitian Psikologi, Vol. 1, No. 1, Juni 2016, h. 36.

${ }^{27}$ Menurut Surya Isham (2018), stimuli ekstern adalah apa saja yang berasal dari luar dan mempengaruhi tubuh, apapun yang menyentuh pada salah satu dari lima indera. Contohnya meliputi perubahan suhu, pemandangan, suara, rasa, dan bau yang dapat mempengaruhi tubuh dan pikiran.rangsangan ekstern dapat mempengaruhi pengambilan keputusan kemampuan seseorang dan pilihan. Lihat https: / / elibrary.unikom.ac.id.

${ }^{28}$ Kartini Kartono dan Jenny Andari, Hygiene Mental dan Kesehatan Mental dalam Islam, (Bandung: Mandar Maju, 1989), h. 80.

${ }^{29}$ Lajnah Pentashihan Mushaf Al-Qur'an, Fenomena Kejiwaan Manusia dalam Perspektif Al-Qur'an dan Sains, (Jakarta: Kementrian Agama RI, 2016), h. 4.
} 
perasaan atau bahkan berupa tindakan. Tertekan, depresi serta alkoholik tergolong menjadi gangguan mental karena adanya defleksi, hal ini bisa disimpulkan bahwa gangguan mental menjadi kunci menurunnya fungsi mental serta berimbas dengan di ketidakwajaran kepribadian. Hal ini sesuai dengan Al-Qur'an dalam surat Al-Baqarah [2]: ayat $10^{30}$

\section{Kesehatan Mental dalam Al-Qur'an}

Kesehatan mental ala Barat teronsentrasi pada diri manusia, sehingga dapat memudaratkan jiwa manusia, sebab pada hakikatnya manusia mempunyai batas dalam memcahkan permasalahan hidup. Paradigma Islam justru menghilangkan diri (self) untuk diserahkan kepada Allah (Hollins, 2006). berhubungan dengan kesehatan jiwa (mental), Islam menganggap bahwa jalinan hubungan dengan Tuhan adalah sumber kebahagiaan, sehingga kebahagiaan dunia dan akhirat sebagai ukuran kebahagiaan hakiki. Keselamatan (kebahagiaan) dunia dan akhirat sebagai hal yang sangat penting untuk menjadi tujuan dan makna hidup manusia. ${ }^{31}$

Terdapat banyak uraian ayat-ayat Al-Qur`an yang berbicara tentang kesehatan mental, baik dari segi fisik, nafs/psikis, sosial, dan spiritual. Ayat-ayat ini terurai menjadi dua bagian, yakni, pertama, konsep dan doktrin yang berhubungan dengan definisi normatif tertentu. Pada bagian ini, kita mengetahui banyak sekali draf yang berkaitan dengan kesehatan, baik yang abstrak maupun yang konkret. Konsep abstrak merangkum konsepkonsep seperti keadaan mental (psikologis), perasaan (emosi), akal dan sebagainya. Sedangkan konsep yang konkrit yang berhubungan dengan corak karakter manusia (personality) antara lain pola karakter yang beriman, pola tempramen munafik, serta pola tempramen kafir yaitu seperti dalam Q.S Ali Imran ayat 110, Q. Al-Fath ayat 92, Q.S AzZariyat ayat 56. Kedua, ayat-ayat yang mengandung sejarah dan amsal-amsal (perumpamaan). Sebagaimana kisah Nabi Ayyub yang sabar dalam melawan cobaaan yang diberikan oleh Allah yakni penyakit, seperti dalam Q.S Al-Anbiya (21) ayat 83-84. ${ }^{32}$

Sementara itu menurut Langgulung, Al-Qur'an mempunyai banyak ayat-ayat yang berhubungan dengan kesehatan mental dengan bermacam-macam term yang dipakai sebagai sesuatu yang hendak dicapai oleh setiap manusia, diantaranya kebahagiaan (sa'adah), keselamatan (hajat), kejayaan (fawz), dan kesempurnaan (al-kamal). ${ }^{33}$

\footnotetext{
30 Abdul Hamid, "Agama dan Kesehatan Mental dalam Perspektif Psikologi Agama”, dalam Jurnal Kesehatan Tadulako, Vol. 3, No. 1, Januari 2017, h. 11.

${ }^{31}$ Qurotul Uyun, "Kesehatan Jiwa Menurut Paradigma Islam (Kajian Berdasarkan Al-Qur'an dan Hadis), http://www.researchgate.net/publication/313531193 KESEHATANIWA MENURUT PARADIGMA ISLAM KAJIAN BERDASARKAN AL QURAN DAN HADIST, diakses pada 18 Juli 2021.

32 Zulkarnain, "Kesehatan dan Mental dan Kebahagiaan: Tinjauan Psikologi Islam", dalam Jurnal Dakwah dan Pengembangan Sosial Kemanusiaan, Vol. 10, No. 1 2019, h. 29-30.

${ }^{33}$ Ramayulis, Psikologi Agama, h. 136.
} 
Di sampimg term kesehatan mental tersebut, Al-Qur'an juga mempunyai banyak ayatayat yang berhubungan dengan penjelasan pengertian kesehatan mental, termasuk ikatan jalinan dengan dirinya sendiri, orang lain, lingkungan, dan Tuhan, dimana semua ini berharga, untuk melaksanakan kehidupan yang bahagia baik di dunia ini dan di masa depan. Sederhananya Al-Qur'an mengungkapkan dengan kalimat âmanû wa 'amilu ashshâlihât di berbagai tempat. Kalimat yang dipakai itu menggunakan kata kerja (fíil). konteks ini tidak salah jika kalimat tersebut disamakan dengan memajukan dan memanfaatkan potensi manusia. ${ }^{34}$

Adapun contoh ayat-ayat Al-Qur'an yang berkorelasi dengan kesehatan mental: ${ }^{35} 1$ ) Ayat yang menjelaskan hubungan dengan diri sendiri (habl min an-nafs). Q.S Ali 'Imran [3]: 110; Q.S Al-Jasiyah [45]:23; 2) Ayat yang menjelaskan jalinan ikatan manusia dan orang lain ( dalam bentuk relasi atau sebaliknya. Q.S Al-Fath [48]: 29; 3) Ayat-ayat yang menjelaskan habl min alam, dimana manusia dapat mengembangkan dan memanfaatkan potensinya untuk memanfaatkan alam seisinya atau merusaknya, Q.S Al-Jumu'ah[62]: 10, Q.S ArRum [30]:41; 4) Ayat-ayat yang menjelaskan habl min Allah, di mana manusia mampun untuk memliki kecenderungan dalam mengembangkan dan memanfaatkan kepiawaiannya dalam bentuk beribadah kepada-Nya atau mengingkari-Nya, Q.S Az-Zariyat [51]: 56, Q.S An-Nahl [16]:73; 5) Ayat-ayat tentang kebahagiaan, Q.S An-Nahl [16]: 97, Q.S AlQashash [28]: 77, Q.S Ali 'Imran [3]: 104; 6) Ayat yang berhubungan dengan ketenangan jiwa, Q.S Ar-Ra'd [13]: 28, Q.S Al-A'raf [7]: 35, Q.S Al-Baqarah [2]: 153, Q.S Al-Fath $[48]: 18$.

\section{Kesehatan mental dalam Tafsir Al-Misbah}

Berikut ini adalah ayat-ayat Al-Qur'an yang berkorelasi dengan kesehatan mental, diantaranya:

1. Ayat-ayat ketentraman dan ketenangan hati

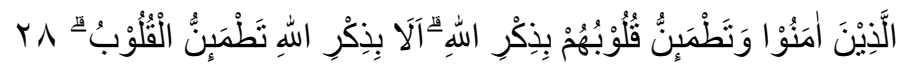

"(Yaitu) orang-orang yang beriman dan hati mereka menjadi tenteram dengan mengingat Allah, ingatlah, hanya dengan mengingat Allah hati menjadi tenteram." (Q.S Ar-Ra'd[13]: 28)

M. Quraish Shihab menafsirkan ayat ini yakni dengan ketentraman hati dapat dicapai dengan mengingat Allah (dzikrullah), zikir yang dirasakan dengan hati dan juga pikiran dan

\footnotetext{
${ }^{34}$ Ramayulis, Psikologi Agama, h. 137.

${ }^{35}$ Ramayulis, Psikologi Agama, h. 137-141.
} 
tidak hanya secara lisan. ketenangan dalam hati akan terus berkelanjutan bila zikir juga dilakukan secara persisten. Ketentraman hati juga dapat diraih bila diiringi dengan iman yang meyakini bahwa Allah sebagai pangkat yang dapat mengkabulkan segala keinginan dan yang tidak dapat dikalahkan. Dalam prinsip kesehatan mental, zikir merupakan jalan untuk meraih kesehatan mental dan equanimity (ketenangan batin) bila dilakukan secara kontinu.

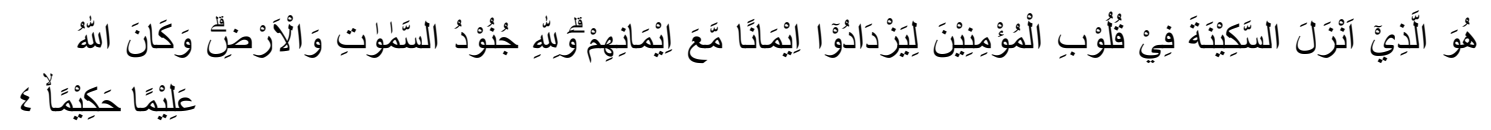

"Dialah yan telah menurunkan ketenangan ke dalam hati orang-orang mukmin untuk menambah keimanan atas keimanan mereka (yang telah ada). Dan milik Allah-lah tentara langit dan bumi, dan Allah Maha Mengetahui, Mahabijaksana.” (Q.S Al-Fath [48]:4)

Penjelasan ayat di atas yaitu sakinah diberikan kepada kaum muslimin adalah salah satu komponen utama untuk mendapatkan kemenangan. Sakinah merupakan ketentraman dalam hati muslimin yang membuat tidak terjadi kegamangan dan percekcokan di antara kaum beriman, sehingga mereka bersatu tidak dibuat ragu oleh setan serta kabar berita yang tidak baik yang disebarluaskan oleh kaum musyrikin dan munafikin. ${ }^{36}$

Quraish Shihab dalam menafsirkan ayat ini yaitu tentang sakinah atau ketentraman hati dirasakan setelah munculnya luapan. Sakinah atau ketenangan hati diberikan oleh Allah karena terdapat kesiapan mental lantaran wujudnya keimanan serta usaha berbentuk kesabaran, ketakwaan, kesetiaan kepada agama sehingga ketenangan hati dapat dirasakan.

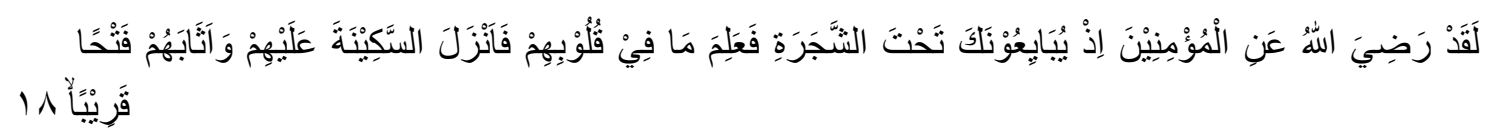

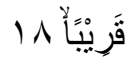

"Sungguh, Allah telah meridai orang-orang mukmin ketika mereka berjanji setia kepadamu (Muhammad) di bawah pohon, Dia mengetahui apa yang ada dalam hati mereka, lalu Dia memberikan ketenangan atas mereka dan memberi balasan dengan kemenangan yang dekat,." (Q.S Al-Fath [48]:18)

M. Quraish Shihab memberi penjelasan, sakinah atau ketenangan hati dalam ayat ini dirasakan karena hadirnya ketaatan dengan kesaksian kesetiaan kepada agama serta keikhlasan. Lebih dari itu, untuk mendatangkan sakinah dalam hati, ada beberapa fase yang harus dilintas. Fase pertama dengan mengakui kesalahan-kesalahan yang telah dilakukan, fase selanjutnya yakni meratapi dan tidak mengulangi perbuatan kedurhakaan tersebut, lalu di fase terakhir yaitu mujahadah atau berusaha untuk memperelok diri dengan ketabahan dan takwa. Fase-fase tersebut disebut juga dengan bertaubat dan suatu yang pedoman dalam kesehatan mental.

${ }^{36}$ M. Quraish Shihab, Tafsir Al-Misbah (Pesan, Kesan dan Keserasian Al-Qur'an), (Bandung: Lentera Hati, 2002), Vol. 6, Cet. Ke-2, h. 512. 


\section{Ayat-ayat kebahagiaan}

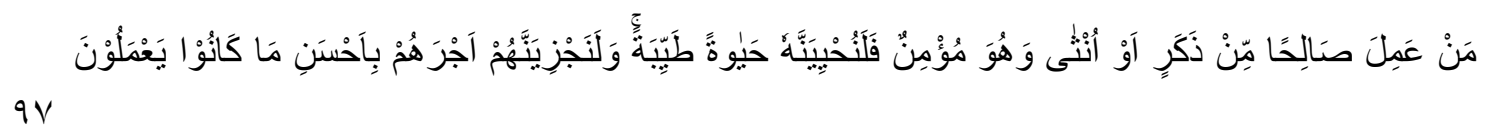

"Barang siapa mengerjakan kebajikan, baik lakiOlaki maupun perempuan dalam keadaan beriman, maka pasti akan kami berikan kepadanya kehidupan yang baik dan akana Kami beri balasan dengan pahala yang lebih baik dari apa yang telah mereka kerjakan.” (Q.S An-Nahl[16]:97)

M. Quraish Shihab memberi penafsiran pada ayat ini dengan berkaitannya amal saleh dengan keimanan yang akan menjadikan hayâtan thayyibatan atau kehidupan yang baik, dimana kehidupan yang baik disini bukan kehidupan yang penuh dengan harta, tetapi kehidupan yang diliputi oleh rasa lega, keridoan, serta kesabaran dalam menerima godaan dan rasa syukur atas nikmat Allah dan sadar akan pilihan Allah-lah yang terbaik. Menyertakan iman dalam beramal saleh memberi impresi pada pelakunya untuk berantusias dalam berkorban dan beramal seotimal mungkin tanpa mengharap imbalan. Keimanan dan amal saleh merupakan elemen utama dalam pembinaan kesehatan mental, sehingga dengan mempersatukan keduanya akan memberi dampak baik yaitu hidup yang bahagia dalam arti hidup yang penuh keikhlasan, kridloaan, rasa tenang dalam menghadapi berbagai cobaan kehidupan. Kebahagiaan hidup tersebut merupakan parameter dari kesehatan mental.

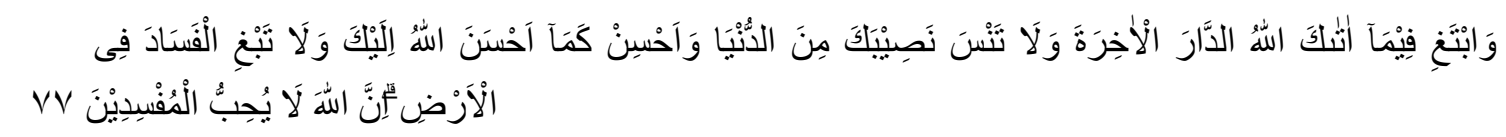

"Dan sarilah (pahala) negeri akhirat dengan apa yang telah dianugerahkan Allah kepada kamu, tetapi jaanganlah kamu lupakan bagianmu di dunia dan berbuat baiklah (kepada orang lain) sebagaimana Allah telah berbuat baik kepadamu, dan janganlah kamu berbuat kerusakan di bumi. Sungguh, Allah tidak menyukai orang yang berbuat kerusakan.” (Q.S Al-Qashash [28]:77)

Quraish Shihab menafsirkan ayat ini bahwa kebahagiaan akhirat harus dicari dengan sungguh-sungguh dan sekuat tenaga tapi juga tidak melupakan kenikmatan dunia. Ayat ini juga menekankan bahwa akhirat itu sebagai misi dan dunia adalah batu loncat untuk meraih misi tersebut. Sehingga perhatian pun harus banyak dialihkan kepada akhirat sebagai haluan, bukan kepada dunia, sebab dunia hanya sebagai batu loncat untuk meraih tujuan itu yaitu kebahagiaan akhirat.

3. Al-Qur'an sebagai obat penyakit jiwa Q.S Yunus (10) ayat 57

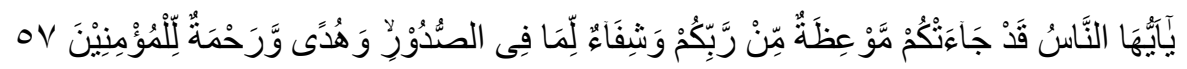


"Wahai manusia! Sungguh, telah datang kepadamu pelajaran (Al-Qur'an) dari Tuhanmu, penyembuh bagi penyakit yangada dalam dada, dan petunjuk serta rahmat bagi oorang yang beriman.” (Q.S Yunus [10]:57)

Dlam ayat ini terdapat empat fungsi yaitu sebagai pengajaran, obat, petunjuk, dan rahmat. Keempat fungsi tersebut memberikan dampak pada jiwa manusia dari jiwa yang dipenuhi keraguan menjadi jiwa yang mantap dan sehat dengan keimanan. Pengajaran menghilangkan keraguan serta melahirkan keimanan dan kewaspadaan, Al-Qur'an merupakan obat untuk penyakit hati, yaitu seperti halnya ragu, dengki, takabur, dan semacamnya hingga psikosomatis. Al-Qur'an juga merupakan petunjuk agar jiwa dapat sehat dan terjaga dari berbagai penyakit atau gangguan jiwa/mental, dan rahmat Al-Qur'an dengan diperolehnya kesehatan jiwa dan kebahagiaan hidup serta terhindar dari segala penyakit.

Dari penjelasan penafsiran di atas, penulis akan menguraikan analisa dari pernafsiran tersebut yang berkaitan dengan kesehatan mental pada beberapa poin sebagai berikut:

Pertama, keimanan, kesabaran, ketakwaan, ketaatan, keridhaan, taubat dan zikir merupakan metode dalam meraih kesehatan mental yaitu berupa ketentraman dan ketenangan dalam hati. Dalam keimanan terdapat dampak yang besar pada manusia, yaitu membuat percaya pada diri sendiri, kesabaran serta kekuataan dalam menanggung penderitaan hidup semakin meningkat, ketenangan serta kedamaian dalam jiwa dan hati terus bangkit, serta menciptakan ketenangan pikiran memberi rasa bahagia. ${ }^{37}$

Kedua, hubungan antara amal saleh dengan iman akan menghasilkan hayâtan thayyibatan yaitu kehidupan yang disertai oleh rasa puas, ridho, serta sabar dalam menerima cobaan dan rasa syukur atas nikmat Allah dan sadar akan pilihan Allah lah yang terbaik. Hal ini juga tidak berlainan dengan gagasan dari Sayyid Quthb dalam kitab Tafsir fi Zhilalil Qur'an, bahwa hayâtan thayyibatan itu tidak harus berlimpah kenikmatan dan kekayaan, tetapi juga dalam bentuk lain yang dapat membuat hidup tenang yaitu ittishal (senantiasa kontak) dengan Allah, tsiqah kepada-Nya dan rasa tenang tengah berada dalam pemeliharaan, penjagaan, dan ridha-Nya. Kenikmatan dalam bentuk lainnya yaitu berupa kesehatan, ketenangan, kesejahteraan, keberkahan, tempat tinggal yang nyaman, dan kedamaian hati dan jiwa. Dapat pula dalam bentuk senang berbuat baik, yang mana berpenggaruh pada hati dan kehidupan. ${ }^{38}$

Ketiga, mengutamakan kebahagiaan akhirat sebagai tujuan dalam kehidupan serta dunia sebagai sarana mencapai tujuan merupakan salah satu usaha dalam pembinaan kesehatan mental. Kebahagiaan sebagai indikator kesehatan mental dalam Al-Qur'an

\footnotetext{
${ }^{37}$ Ramayulis, Psikologi Agama, h. 159.

${ }^{38}$ Sayyid Quthb, Tafsir fi Zhilalil Qur'an di Bawah Naungan Al-Qur'an, terj. As'ad Yasin dkk, (Jakarta: Gema Insani Press, 2003), jilid 7, h. 212.
} 
ditunjukkan dengan kebahagian hakiki yaitu kebahagiaan akhirat. Untuk mencapai kebahagiaan akhirat tersebut, manusia diperintahkan mencarinya dengan sungguh-sungguh tanpa meninggalkan kenikmatan dunia. Karena bila hanya terfokus mencari kenikmatan dunia saja yang bersifat sementara ini hanya akan mengakibatkan penyakit hati yakni cinta pada dunia dan takut akan kematian. Disamping upaya mencari kebahagiaan akhirat dengan sungguh-sungguh, untuk mencapai kebahagiaan bisa diraih dengan beramal saleh dengan menyertakan keimanan. Amal saleh merupakan upaya mengoptimalkan potensi dalam diri seseorang semaksimal mungkin dan memanfaatkannya pada diri sendiri dan orang lain.

Keempat, keimanan merupakan faktor penting dalam mencapai kesehatan mental. Semakin tinggi keimanan maka semakin sehat juga mental seseorang. Orang yang beriman juga mempunyai sikap penyerahan diri kepada Allah sebagai suatu zat yang mempunyai kuasa yang tinggi. Sikap pasrah tersebut diyakini dapat memberikan optimisme dan menciptakan rasa gembira, senang, lega, serta merasa dicintai atau rasa aman. Sikap emosi tersebut adalah bagian dari kebutuhan manusia sebagai makhluk yang bertuhan. Dengan kata lain, manusia berada dalam kondisi tenang dan normal, yang oleh Muhammah Mahmud Abd al-Qadir, disebut tengah berada dalam ekuilibrium persenyawaan kimia dan hormon tubuh. Dengan kata lain, kondisi yang telah disebutkan membuat manusia pada keadaan takdirnya, sesuai dengan fitrah kejadiannya, sehat jasmani dan rohani. ${ }^{39}$

Kelima, Al-Qur'an berfungsi sebagai psikoterapi yaitu obat untuk penyakit jiwa dan psikosomatik. Psikoterapi merupakan proses penyembuhan secara psikologis bagi permasalahan yang berhubungan dengan pikiran, emosi, serta tingkah laku. ${ }^{40}$ Adapun AlQur'an berperan sebagai solusi dari permasalahan kesehatan mental, yaitu sebagai obat bagi penyakit-penyakit ruhani. Selain itu, terdapat berbagai macam metode penyembuhan pada gangguan mental yang disebut dalam Al-Qur'an. Diantara metode dalam penyembuhan gangguan kesehatan mental yaitu dengan zikir. Membaca Al-Qur'an dengan menghayati setiap makna-maknanya juga merupakan bagian dari zikir dan metode merawat kesehatan mental. Apalagi bila ditambah dengan tidak hanya membaca dengan menghayati maknamaknanya saja, tetapi juga diaplikasikan dalam aktivitas.

Esensi Al-Qur'an seringkali juga disebut sebagai syifâ' fi ash-shudûr, karena dapat menenangkan jiwa yang kacau dan gelisah. Aspek keimanan dalam ilmu kesehatan mental adalah sesuatu yang paling mendasar dan begitu penting. Kesehatan mental dapat ditandai dengan terwujudnya keimanan yang kuat dan konsisten, karena seorang muslim menjalin

\footnotetext{
${ }^{39}$ Ramayulis, Psikologi Agama, h. 134.

${ }^{40}$ Alam Budi Kusuma, "Pendekatan Psychoterapy Al-Qur'an dalam Gangguan Kesehatan Mental (Suatu kajian Psikologi Agama)", h. 138.
} 
hubungan baik dengan Tuhan melalui beribadah kepada-Nya. Mental yang sehat dan kuat yang teraplikasi dengan baik dapat menghasilkan psikologis tenang dan tenteram. ${ }^{41}$

\section{Relevansi Penafsiran M. Quraish Shihab Terhadap Kesehatan Mental di Era Modern}

Pada uraian ini penulis akan mengaitkan konsep kesehatan mental penafsiran $\mathrm{M}$. Quraish Shihab terhadap kesehatan mental di era modern dengan menghubungkannya dengan teori hierarki kebutuhan oleh Abraham H. Maslow (w. 1970 M) atau Maslow's Hierarchy of Needs. Ia berpendapat bahwa hal yang menjadi motivasi ketika kebutuhan pada tingkat terendah harus terpenuhi dulu sebelum pada kebutuhan pada tingkat paling tinggi. Maslow menggolongkan lima keperluan pokok manusia dalam bentuk piramida tingkatan yang diawali dengan keperluan fisiologis, keamanan (safety), dimiliki dan cinta (belonging and love), harga diri (self esteem), dan kebutuhan aktualisasi diri (selfactualization Needs).

Konsep kesehatan mental perspektif M. Quraish Shihab mempunyai relevansi terhadap kesehatan mental modern pada teori hierarki kebutuhan Abraham H. Maslow. Tingkat kebutuhan Maslow ini dapat menjadi motivasi dalam memperoleh dan menjaga kesehatan mental. Akidah dan spiritualitas merupakan tingkat kebutuhan tertinggi yaitu aktualisasi diri, dan kenikmatan dunia merupakan tingkat kebutuhan paling dasar yaitu kebutuhan fisiologis. Berikut ini urutan tingkat kebutuhan pada konsep kesehatan mental dalam penafsiran M. Quraish Shihab: a) Kebutuhan fisiologis, dalam konsep kesehatan mental perspektif penafsiran M. Quraish Shihab berhubungan dengan kenikmatan dunia dalam arti keperluan akan sandang, pangan, dan papan; b) keperluan keamanan (safety needs), dalam penafsiran Quraish Shihab berhubungan dengan zikir, sikap sabar dan ridho; c) keperluan akan rasa memiliki dan kasih sayang (social needs), berhubungan dengan ibadah dalam arti luas dalam bentuk muamalah; d) keperluan manifestasi diri (selfactualization Needs), berkaitan dengan akidah dan spiritualitas, serta menyeimbangkan kebutuhan material dan spiritual.

\section{PENUTUP}

Penafsiran M. Quraish Shihab mengenai kesehatan mental mempunyai keterkaitan dengan keimanan kepada Allah swt. serta upaya dalam memelihara dan memperoleh kesehatan mental. Keimanan, kesabaran, ikhlas, rasa syukur, ketakwaan, ketaatan, keridhaan, taubat dan zikir merupakan metode dalam meraih kesehatan mental yaitu berupa ketentraman dan ketenangan dalam hati. Keterikatan antara amal saleh dengan

${ }^{41}$ Samain, “Konsep Kesehatan Mental dalam Al-Qur'an dan Implikasinya Terhadap Adversity Quotient Perspektif Tafsir Al-Misbah”, h. 20. 
keimanan tidak hanya memberikan kehidupan yang indah di dunia tetapi juga kebahagiaan yang hakiki di akhirat. Mengutamakan kebahagiaan akhirat sebagai target sasaran dan dunia sebagai batu loncat untuk mendapatkan sasaran dalam kehidupan merupakan salah satu usaha pembinaan kesehatan mental. Al-Qur'an merupakan psikoterapi bagi penyakit jiwa dan penyakit psikosomatik.

Relevansi penafsiran kesehatan mental perspektif M. Quraish Shihab terhadap kesehatan mental di era modern mempunyai keterkaitan dengan teori hierarki kebutuhan Abraham H. Maslow. Tingkat kebutuhan Maslow ini dapat menjadi motivasi dalam memperoleh dan menjaga kesehatan mental. Akidah dan spiritualitas merupakan tingkat kebutuhan tertinggi yaitu aktualisasi diri, dan kenikmatan dunia merupakan tingkat kebutuhan paling dasar yaitu kebutuhan fisiologis. Konsep kesehatan mental perspektif penafsiran M. Quraish Shihab berdasarkan hierarki kebutuhan Abraham Maslow dapat dibeberkan sebagai berikut: tingkatan keperluan paling dasar yaitu keperluan fisiologis berhubungan dengan kenikmatan dunia; kebutuhan akan keamanan (safety needs), berhubungan dengan zikir, sikap sabar dan ridho; keperluan akan rasa memiliki dan kasih sayang (social needs), berhubungan dengan ibadah dalam arti luas dalam bentuk muamalah; dan kebutuhan manifestasi diri (self-actualization Needs), yaitu berkaitan dengan akidah dan spiritualitas, serta menyeimbangkan kebutuhan material dan spiritual.

\section{DAFTAR PUSTAKA}

Abdul Aziz, "Survei: 64,3\% dari 1.522 Orang Cemas dan Depresi Karena Covid-19", http://tirto.id/survei-643-dari-1522-orang-cemas-depresi-karena-covid-19-fgPG.

Adriansyah, Rian, "Konsep Akal Dalam Tafsir Al-Misbah”, Skripsi, Lampung: UIN Raden Intam Lampung, 2018.

Arifin, Zaenal, "Karakteristik Tafsir Al-Misbah”, dalam Jurnal Al-Ifkar Vol. 13 No. 01, Maret 2020.

Brutu, Ali Geno, "Tafsir Al-Misbah: Muhammad Quraish Shihab", dalam Jurnal Online Preprints, Vol. 14, 2017.

Drajat, Zakiah, Islam dan Kesehatan Mental, Jakarta: Gunung Agung, 1983.

Fuad, Ikhwan, "Menjaga Kesehatan Mental Perspektif Al-Qur'an dan Hadis", dalam Jurnal An-Nafs: Kajian dan Penelitian Psikologi, Vol. 1, No. 1, Juni 2016.

Hamid, Abdul, "Agama dan Kesehatan Mental dalam Perspektif Psikologi Agama”, dalam Jurnal Kesehatan Tadulako, Vol. 3, No. 1, Januari 2017

HS, Muhammad Alwi, dkk, "Gerakan Membumikan Tafsir Al-Qur'an di Indonesia: Studi M. Quraish Shihab atas Tafsir Al-Misbah”, dalam Jurnal Al-Tibyan: Jurnal Ilmu Al-Qur'an dan Tafsir Vol. 5 No. 1, Juni 2020.

Kartono, Kartini dan Jenny Andari, Hygiene Mental dan Kesehatan Mental dalam Islam, Bandung: Mandar Maju, 1989. 
Kusuma, Alam Budi, "Pendekatan Psychoterapy Al-Qur'an dalam Gangguan Kesehatan Mental (Suatu kajian Psikologi Agama)", dalam Jurnal Komunikasi dan Pendidikan Islam, Vol. 5, No. 1, Juni 2016.

Lajnah Pentashihan Mushaf Al-Qur'an, Fenomena Kejiwaan Manusia dalam Perspektif AlQur'an dan Sains, Jakarta: Kementrian Agama RI, 2016.

Lufaefi,"Tafsir Al-Misbah: Tekstualitas, Rasionalitas, dan Lokalitas Tafsir Nusantara", dalam Jurnal Substantia Vol. 21 No. 1 April 2019Shihab, M. Quraish, Tafsir Al-Misbah (Pesan, Kesan dan Keserasian Al-Qur'an), Bandung: Lentera Hati, 2002, Vol. 6, Cet. Ke-2.

Malikah, "Pendidikan Kesehatan Mental Melalui Bacaan Al-Qur'an (Studi Kasus di Pesantren Darullughah Wadda'wah Raci Bangil Pasuruan dan Pesantren Al-Amanah Bilingual Junwangi Krian Sidoarjo)”, Disertasi, Surabaya: Pascasarjana UIN Sunan Ampel , 2018.

Qurotul Uyun, "Kesehatan Jiwa Menurut Paradigma Islam (Kajian Berdasarkan Al-Qur’an dan Hadis), http://www.researchgate.net/publication/313531193_KESEHATANIIWA MENURUT PARADIGMA ISLAM KAJIAN BERDASARKAN AL QURA N_DAN_HADIST.n Metodologi Tafsir Al-Misbah Karya M. Quraish Shihab, http://digilib.iunsgd.ac.id.

Quthb, Sayyid, Tafsir fi Zhilalil Qur'an di Bawah Naungan Al-Qur'an, terj. As'ad Yasin dkk, Jakarta: Gema Insani Press, 2003, Jilid 7.

Radiani, Widiya A, "Kesehatan Mental Masa Kini dan Penanganan Gangguannya Secara Islmai”, dalam Journal of Islamic and Law Studies, Vol. 3, No. 1, Juni 2019.

Ramayulis, Psikologi Agama, Jakarta: Kalam Mulia, 2013.

Ratnawati, "Metode Perawatan Kesehatan Mental dalam Islam", dalam Jurnal Islamic Counseling: Jurnal Bimbingan dan Konseling Islam, Vol. , No. 1, 2019.

Samain, "Konsep Kesehatan Mental dalam Al-Qur'an dan Implikasinya Terhadap Adversity Quotient Perspektif Tafsir Al-Misbah”, Tesis, Salatiga: IAIN Salatiga, 2020.

Shihab, M. Quraish, Tafsir Al-Misbah (Pesan, Kesan dan Keserasian Al-Qur'an), Bandung: Lentera Hati, 2002, Vol. 6, Cet. Ke-2.

Wartini, Atik, "Corak Penafsiran M. Quraish Shihab dalam Tafsir Al-Misbah", dalam Jurnal Hunafa: Jurnal Studia Islamika, Vol. 11 No. 1, Juni 2014.

Yusuf, Syamsu, Kesehatan Mental perspektif Psikologis dan Agama, Bandung: PT Remaja Rosdakarya, 2018.

Zamimah, Iffaty, Al-Wasathiyyah dalam Al-Qur'an (Studdi Tafsir Maraghi, Al-Munir, dan AlMisbah), Tangerang: IIQ Jakarta Press, 2019.

Zulkarnain, "Kesehatan dan Mental dan Kebahagiaan: Tinjauan Psikologi Islam", dalam Jurnal Dakwah dan Pengembangan Sosial Kemanusiaan, Vol. 10, No. 12019. 